\title{
PENGARUH STATUS QUO, HERDING BEHAVIOUR, REPRESENTATIVENESS BIAS, MENTAL ACCOUNTING, SERTA REGRET AVERSION BIAS TERHADAP KEPUTUSAN INVESTASI INVESTOR MILENIAL DI KOTA SURABAYA
}

\author{
Syifa Aulia Mahadevi \\ Universitas Negeri Surabaya \\ syifaauliamahadevi@gmail.com \\ Nadia Asandimitra \\ Universitas Negeri Surabaya \\ nadiaharyono@unesa.ac.id
}

\begin{abstract}
Abstrack
Investment activity in Indonesia steadily increases as more people become aware of the investment's value and potential returns. This study aims to determine the impact of status quo bias, herding behavior, representation, and mental accounting on the investment decisions of millennial investors in Surabaya. This study is conclusive because it used purposive and snowball sampling techniques to obtain samples by distributing online questionnaires - the research sample as many as 241 respondents. The analysis technique uses Structural Equation Model (SEM). This study focuses on millennial investors registered with the Indonesian Central Securities Depository (KSEI) and securities firms in Surabaya. The findings suggest that the variables status quo and regret aversion significantly bias investment decisions, whereas herding behavior, representativeness, and mental accounting do not affect investment decisions. Thus, this study can assist various parties, particularly millennial investors, pay more attention to their biases and be more cautious when making investment decisions.
\end{abstract}

Keywords : behavioral finance; investment decision; millennial investor

\section{PENDAHULUAN}

Globalisasi merupakan salah satu turbulensi penting yang perlu diperhatikan oleh setiap individu maupun negara. Salah satu dampak positif dari globalisasi adalah peningkatan pertumbuhan ekonomi suatu negara yang dipengaruhi oleh banyak faktor, diantaranya tingkat investasi. Adanya tingkat investasi yang tinggi akan mendorong pertumbuhan yang positif dalam perkembangan ekonomi suatu negara. Investasi adalah penanaman sejumlah dana pada masa sekarang untuk mendapatkan keuntungan dimasa depan (Syahyunan, 2015). Aktivitas investasi di Indonesia selalu mengalami peningkatan karena semakin banyak masyarakat yang sadar terhadap pentingnya investasi serta return yang didapatkan. Peningkatan ini tercermin pada Single Investor Identification (SID) atau jumlah Investor perorangan berdasarkan data dari KSEI sebagai berikut :

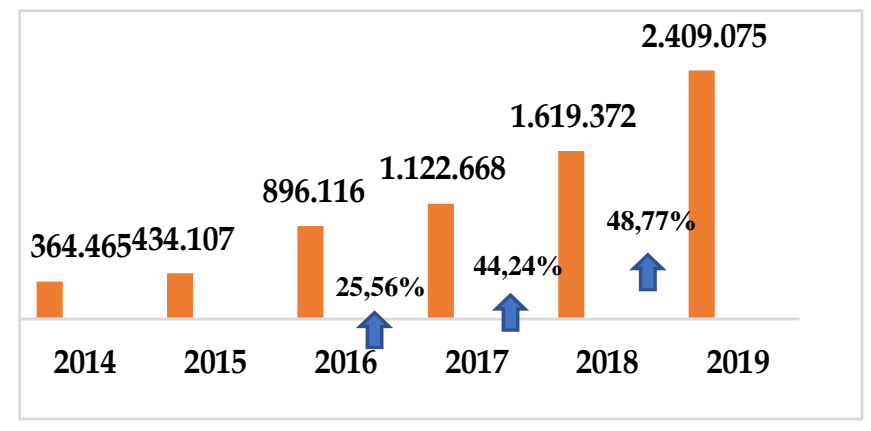

Sumber : KSEI (data diolah penulis, 2019)

Gambar 1. KENAIKAN JUMLAH SINGLE INVESTOR IDENTIFICATION 
Syifa Aulia Mahadevi \& Nadia Asandimitra Haryono. Pengaruh Status Quo, Herding Behaviour, Representativeness Bias, Mental Accounting, serta Regret Aversion Bias terhadap Keputusan Investasi Investor Milenial di Kota Surabaya

Tahun 2014 hingga 2019, jumlah SID (Single Investor Identification) terus mengalami kenaikan seperti pada gambar 1. Pada 2014 jumlah SID yang tercatat di KSEI mencapai 364.465, sedangkan akhir tahun 2019 jumlah SID yang tercatat di KSEI meningkat menjadi 2.409.075 SID atau meningkat sebesar 560\%. Pada 2019, jumlah Single Investor Identification (SID) mengalami peningkatan sebesar 48,77\% dari 1.619.372 menjadi 2.409.075 SID, aktivitas investasi serta kenaikan Single Investor Identification (SID) pada pasar modal tentunya akan berhubungan dengan penentuan keputusan investasi yang dilakukan oleh seorang investor (KSEI, 2019). Berdasarkan data KSEI (2020) Investor ritel di Indonesia didominasi oleh generasi milenial berusia 21-30 tahun sebesar 44,65\% dari total 2,4 juta investor. Jumlah ini meningkat dari tahun sebelumnya yaitu sebesar $43,28 \%$ di tahun 2019. The Indonesia Capital Market Institute (TICMI) menemukan 61,76\% dari 168 responden milenial telah menerapkan pengelolaan keuangan dengan investasi. Hal ini menunjukkan tingginya minat investasi bagi kaum milenial. Generasi milenial adalah generasi yang lahir pada kisaran tahun 1980 hingga 2000-an, mereka lebih cakap dalam penggunaan teknologi daripada generasi sebelumnya karena mereka tumbuh bersamaan dengan kemajuan teknologi (Budiati et al., 2018).

Pulau Jawa menjadi daerah dengan persebaran investor terbanyak di Indonesia yaitu sebesar 71,46\%, dengan Provinsi Jawa Timur yang memiliki jumlah investor terbanyak mencapai 139.187 SID atau 0,35\% dari total penduduk Jawa Timur sebanyak 40 juta jiwa (KSEI, 2019). Data persebaran wilayah beserta persentase Single Investor Identification (SID) investor yang ada di Jawa Timur di gambar 2.

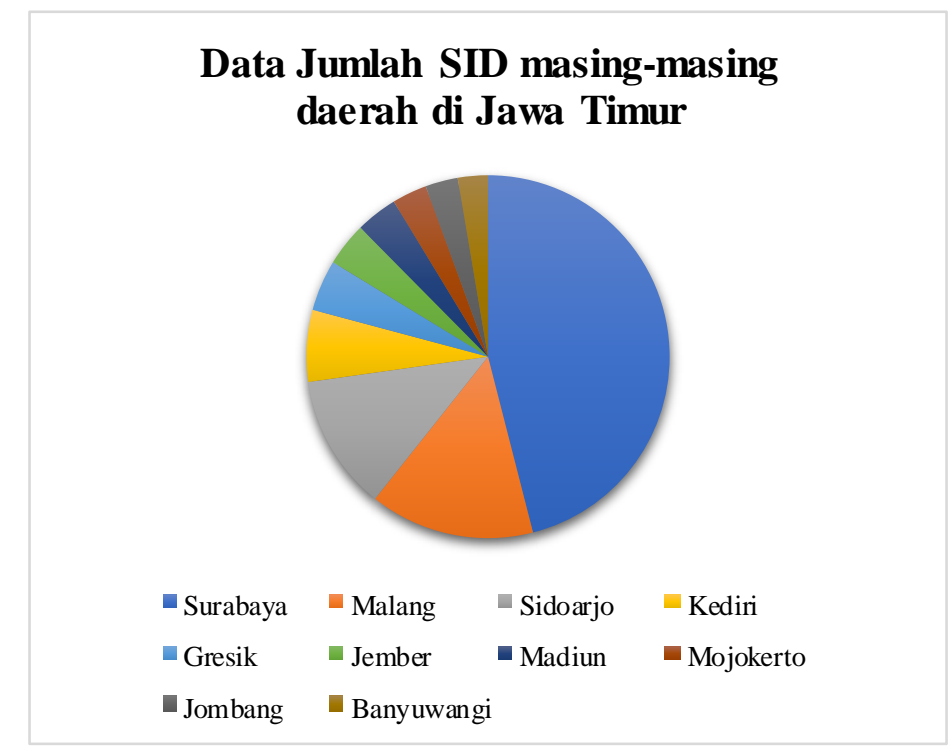

Sumber : KSEI (data diolah penulis, 2019)

\section{Gambar 2. PERSEBARAN WILAYAH BESERTA PERSENTASE SID INVESTOR YANG} ADA DI JAWA TIMUR

Berdasarkan gambar 2, persebaran SID investor terbanyak di Jawa Timur berada di Kota Surabaya yaitu sebanyak 48.626 SID, kemudian disusul dengan Kota Malang 15.498 SID, Sidoarjo 12.768 SID, Kediri 6.758 SID, Gresik 4.809 SID, Jember 4.102 SID, Madiun 3.927 SID, Mojokerto 3.289 SID, Jombang 3.058 SID, Banyuwangi 2.832 SID, data per bulan September 2019. Hal ini mengindikasikan bahwa minat investasi masyarakat di Kota Surabaya merupakan yang tertinggi dari wilayah lain di Jawa Timur. Keberhasilan seorang investor dalam berinvestasi tergantung seberapa tepat investor tersebut menentukan keputusan investasi yang diambilnya baik dalam segi jenis investasi maupun waktu sehingga keuntungan yang didapatkan akan maksimal. Pengambilan keputusan investasi bukan hal yang mudah karena mengandung banyak risiko, ketidakpastian dan berhubungan dengan keberhasilan di masa depan. Berdasarkan research gap dari penelitian terdahulu, terdapat berbagai macam bias dalam perilaku keuangan (behavioural finance) yang memengaruhi keputusan investasi, seperti status quo, herding behaviour, representativeness bias, mental 
accounting, serta regret aversion bias. Menurut Pompian (2006), status quo bias menunjukkan kondisi investor yang menghindari perubahan dan lebih menyukai keadaan investasi yang sama. Adanya status quo ini memengaruhi keputusan investasi seorang investor. Hal ini sejalan dengan penelitian Pradana (2018), Brown \& Kagel (2009), Umairah (2012) yang menyatakan bahwa status quo berpengaruh positif terhadap keputusan investasi, namun tidak sejalan dengan Akinkoye \& Bankole (2020) serta Bashir et al. (2013) yang menunjukkan bahwa status quo tidak berpengaruh signifikan terhadap keputusan investasi.

Herding behaviour merupakan sebuah bias perilaku meniru penilaian investor lain ketika pengambilan keputusan investasi, di mana investor yang mulanya berperilaku secara rasional mulai bertindak secara tidak rasional (Khalid et al., 2018). Herding behaviour disebabkan karena adanya faktor ketidakpercayaan diri pada kemampuan dan pengalaman pribadinya, investor biasanya bereaksi cepat terhadap penilaian keputusan investasi investor lain (Ramdani, 2016). Hal ini didukung Akinkoye \& Bankole (2020), Madaan \& Singh (2019), Mutawally \& Haryono (2019) dan Mahmood et al. (2020), herding behaviour berpengaruh secara signifikan terhadap keputusan investasi. Namun tidak sejalan dengan Gozalie \& Anastasia (2015), Subash (2012) dan Khalid, Javed, \& Shahzad (2018) bahwa tidak ada pengaruh signifikan antara herding behaviour dengan keputusan investasi.

Representativeness adalah kecenderungan seorang investor mengaitkan peristiwa baru dengan peristiwa yang diketahui (pemikiran stereotip) dan melakukan investasi berdasarkan peristiwa tersebut (Subash, 2012). Investor dengan representativeness bias cenderung mempertimbangkan kinerja masa lalu suatu saham sebelum berinvestasi. Hal ini mengindikasikan bahwa representativeness bias dapat memengaruhi bagaimana keputusan investasi seorang investor yang didukung penelitian S. Putri \& Halmawati (2020), Budiman \& Ervina (2020), serta Subash (2012) bahwa representativeness bias mempunyai pengaruh yang signifikan terhadap keputusan investasi. Namun bertolak belakang dengan Irjayanti \& Kurniawati (2017) yang menyebutkan representativeness bias tidak berpengaruh secara signifikan terhadap keputusan investasi.

Mental accounting merupakan sebuah perilaku di mana seorang investor mengkategorikan dan mengevaluasi input dan output hasil ekonominya (Bashir et al., 2013). Mencari jalan keluar untuk menyelamatkan posisi saham yang sedang mengalami kerugian dengan membuat seolah-olah terdapat akun tersendiri pada saham tersebut merupakan fokus utama seorang investor dengan pemahaman mental accounting (Kontan, 2019). Mental accounting berpengaruh terhadap keputusan investasi, hal ini didukung dengan penelitian dari Abdani \& Nurdin (2019), Sari (2015), Santi, Sahara, \& Kamaludin (2019) bahwa mental accounting berpengaruh terhadap pengambilan keputusan investasi. Hal ini berbeda dengan Subash (2012), Bashir et al. (2013) yang menyatakan bahwa ada pengaruh tidak signifikan antara variabel mental accounting terhadap keputusan investasi, artinya semakin baik mental accounting responden maka responden semakin memertimbangkan tingkat risiko yang akan dihadapi dari suatu jenis investasi.

Regret aversion bias adalah sebuah kecenderungan investor menghindari rasa sakit akibat penyesalan di masa lalu karena kesalahan terhadap pengambilan keputusan yang menyebabkan hasil kurang optimal (Akinkoye \& Bankole, 2020). Menurut Budiarto (2017), regret aversion bias menyebabkan investor enggan melepaskan instrumen investasi yang mereka miliki dalam waktu lama yang seharusnya telah dijual untuk mendapatkan keuntungan. Regret aversion bias memengaruhi keputusan investor, sesuai dengan Pradana (2018), Putri \& Hikmah (2020), Nurdinda, Muslihat, \& Putra (2020), Akinkoye \& Bankole (2020) dan Subash (2012) bahwa variabel regret aversion bias berpengaruh terhadap keputusan investasi. Pelaku investasi berisiko tinggi memiliki tingkat risk tolerance yang tinggi. Namun penelitian tersebut berbeda dengan Pujiyanto \& Mahastanti (2013), dan Budiman \& Ervina (2020), regret aversion bias tidak menjadi pengaruh utama dalam pengambilan keputusan investasi. Berdasarkan analisis yang telah dipaparkan, maka penelitian ini bertujuan untuk mengetahui pengaruh status quo, herding behaviour, representativeness bias, mental accounting, serta regret aversion bias terhadap keputusan investasi investor milenial di Kota Surabaya. 
Syifa Aulia Mahadevi \& Nadia Asandimitra Haryono. Pengaruh Status Quo, Herding Behaviour, Representativeness Bias, Mental Accounting, serta Regret Aversion Bias terhadap Keputusan Investasi Investor Milenial di Kota Surabaya

\section{KAJIAN PUSTAKA DAN PENGEMBANGAN HIPOTESIS}

\section{Behavioral Finance Theory}

Behavioral finance theory menjelaskan faktor psikologi seseorang mendasari tindakan yang dilakukan, di mana sikap rasional tidak selalu menjadi dasar tindakan mereka namun juga sikap irrasional yang mereka miliki (Fridana \& Asandimitra, 2020). Behavioral finance theory memelajari bagaimana fenomena psikologi memengaruhi proses pengambilan keputusan berinvestasi dari seorang investor dan hasil yang akan dicapai (Widanti, Afrima \& Alfansi, 2013). Terdapat dua kategori yang menjelaskan tindakan irrasional seseorang yaitu, informasi yang didapatkan oleh seorang investor tidak selalu dikelola dengan baik sehingga peluang porsi tingkat return masa mendatang menjadi tidak optimal, yang kedua investor yang bertransaksi pada keadaan kurang menguntungkan sehingga pengambilan keputusan tidak konsisten (Gupta, 2019). Pompian (2006) menyebutkan dalam bukunya, bias dibagi menjadi dua kategori yaitu cognitive bias dan emotional bias, yang termasuk didalamnya herding behaviour dan status quo bias sebagai variabel independen dalam penelitian ini.

\section{Prespect Theory}

Prespect theory mengasumsikan bahwa dalam keadaan ketidakpastian keputusan seorang investor dimotivasi secara terus menerus oleh faktor-faktor psikologisnya (Pradikasari \& Isbanah, 2018). Prespect theory ini dijelaskan pertama kali oleh Kahneman and Tversky (1979) bahwa dalam praktiknya pengambilan keputusan investasi tidak hanya dengan pertimbangan rasional karena rasionalitas juga sering dilanggar (Prawirasasra \& Dialysa, 2015). Kahneman \& Tversky (1979) menyebutkan terdapat prinsip-prinsip dalam prespect theory yaitu fungsi nilai (value function), pembingkaian (framing), perhitungan psikologis (psychological accounting), probabilitas (probability), serta efek kepastian (certainty effect). Prospect Theory digunakan untuk menjelaskan variabel regret aversion bias dan mental accounting dalam memengaruhi keputusan investasi.

\section{Heuristic Theory}

Heuristic theory merupakan sebuah aturan praktis yang menjadikan sebuah keputusan investasi dalam hal tidak pasti dan kompleks menjadi lebih mudah untuk dilaksanakan. Dalam heuristic theory sebuah pengambilan keputusan dapat menjadi lebih cepat dan teliti katika pengambilan keputusan lebih fokus terhadap informasi penting dan mengabaikan informasi yang kurang bermanfaat (Ratnadi et al., 2020). Namun, ketika heuristic tidak diterapkan dengan baik dan tepat akan mengakibatkan bias dalam pengambilan keputusan. Lanka \& Kengatharan (2014) mengemukakan terdapat lima variabel yang terdapat dalam heuristic theory yaitu representativeness, overconfidence, anchoring, gambler's fallacy, availability. Oleh karena itu salah satu variabel independen dalam penelitian ini adalah representativeness yang dapat memengaruhi keputusan investasi seorang investor.

\section{Keputusan Investasi}

Keputusan investasi adalah kebijakan mengalokasikan dana atau penanaman modal dalam bentuk investasi demi mendapatkan keuntungan di masa depan dalam satu atau lebih aset (Wulandari \& Iramani, 2014). Secara garis besar keputusan investasi dibedakan menjadi dua yaitu keputusan investasi jangka panjang dan keputusan investasi jangka pendek. Tandelilin (2010) menjelaskan bahwa tahap keputusan investasi dibedakan menjadi 5 yaitu, menentukan tujuan investasi, kebijakan investasi, strategi portofolio, penentuan aset serta evaluasi dan pengukuran kinerja portofolio. Ullah (2015) menyebutkan indikator yang dapat digunakan sebagai pengukur keputusan investasi yang meliputi uang adalah tujuan paling penting dalam hidup, merasa puas jika dapat menghemat uang dari pada diinvestasikan, pasar saham tidak bisa diprediksi sehingga enggan melakukan investasi, melakukan investasi uang pada saham, ketidakpastian harga saham menjadi alasan untuk tidak membeli saham, menghemat uang karena tidak tahu kapan tidak memilikinya, lebih suka menabung karena tidak tahu kapan membutuhkan uang, mengelola uang dengan baik.

\section{Status Quo Bias}

Status quo bias adalah sebuah kondisi seorang investor dalam mempertahankan keputusan investasinya saat ini atau masa lalu pada keadaan yang tidak proporsional serta tetap tidak melakukan 
apapun dalam kemungkinan yang terus menerus terjadi (Pradana, 2018). Seorang investor dengan status quo bias cenderung merasa nyaman dengan keputusan yang mereka pegang tanpa melihat keadaan pasar yang sebenarnya sehingga tanpa sadar memertahankan portofolio dengan karakteristik risiko yang tidak tepat. Terdapat beberapa faktor yang dapat memicu seseorang memiliki status quo bias seperti perasaan puas terhadap aset yang mereka investasikan dan loyalitas yang dimiliki. Pompian (2006), menyebutkan terdapat dua Indikator yang dapat digunakan sebagai pengukur status quo bias yaitu tetap pada keadaan yang sama saat berinvestasi, memilih berinvestasi pada surat berharga yang disukai dan familiar.

\section{Herding Behaviour}

Herding behaviour merupakan kecenderungan perilaku seorang investor untuk mengikuti keputusan investor mayoritas (Afriani \& Halmawati, 2019). Seorang invetor dengan herding behaviour kurang percaya terhadap informasi dan kemampuan yang dimiliki sehingga meniru keputusan yang dilakukan investor lain dengan harapan meminimalisir risiko yang muncul. Pengukuran herding behaviour merujuk pada Luong \& Thu Ha (2011) dengan indikator antara lain mengikuti review investor lain dalam keputusan investasi yang dipilih, mengikuti keputusan investor lain dalam penentuan pembelian volume saham, keputusan dalam membeli dan menjual saham berdasarkan pada keputusan investor lain, mengikuti reaksi keputusan investor lain dalam pasar modal secara cepat.

\section{Representativeness}

Representativeness adalah perilaku seorang investor untuk membentuk opini sebuah kelompok dengan bergantung pada stereotip dan analogi yang dimiliki (Ross et al., 2016). Adanya representativeness memunculkan perspektik psikologis disebabkan oleh perilaku investor yang memandang bahwa ketika keadaan perusahaan dan trend harga sebuah surat berharga bagus maka investasi yang akan dilakukan juga bagus. Hal ini berhubungan dengan buku dari Ackert \& Deaves (2010:142) dengan asumsi seorang investor menganggap bahwa good company is good investment. Menurut Noor (2010), Indikator yang dapat digunakan untuk menyebutkan representativeness adalah mempertimbangkan tanggung jawab sosial yang ditetapkan perusahaan saat melakukan investasi, salah satu indikator utama saat melakukan keputusan investasi adalah tingkat tanggung jawab sosial perusahaan, tidak melakukan investasi pada perusahaan yang menerapkan program outsourcing pekerjanya, tidak melakukan investasi pada perusahaan yang menetapkan pemindahan pekerjaan karyawannya ke luar negeri, melakukan pembelian pada saham yang sedang populer atau diminati dan menghindari saham yang buruk pada masa lalu.

\section{Mental aAccounting}

Mental accounting merupakan kebiasaan investor dalam hal menggolongkan keuangan yang mereka dapatkan dalam rekening yang berbeda berdasarkan kriteria tertentu. (Priantinah \& Si, 2018). Mental accounting tidak hanya berkaitan dengan masalah keuangan seseorang namun juga dapat mencakup perilaku secara luas seperti penentuan pengambilan keputusan (Santi, Sahara, \& Kamaludin 2019). Dengan adanya pemahaman mental accounting yang baik diharapkan sebelum seorang investor melakukan keputusan investasi mereka mampu memahami dengan baik bagaimana faktor psikologis yang mendasarinya. Seseorang dengan pemahaman mental accounting juga cenderung mempertimbangkan bagaimana pengeluaran dan pendapatan yang mereka peroleh dari berinvestasi (Sari, 2015). Mental accounting dapat diukur menggunakan indikator dari (Santi, Sahara, \& Kamaludin 2019) yaitu investor akan mengalokasikan pendapatan yang diperoleh dalam beberapa akun yang berbeda, investor mengelola penghasilan bulanan dan bonus yang didapatkan secara berbeda, biaya yang dikeluarkan dari uang bulanan selalu diperhitungkan, biaya yang akan dikeluarkan dari uang bonus selalu diperhitungkan.

\section{Regret Aversion Bias}

Regret aversion bias adalah suatu keadaan psikologis investor yang muncul karena rasa menyesal akibat pengambilan keputusan investasi yang salah sehingga memunculkan motif kehati hatian agar dapat menghindari risiko kesalahan yang sama (Akinkoye \& Bankole, 2020). Gupta (2019) menjelaskan terdapat dua jenis kesalahan yang membuat seorang investor cenderung menghindari 
Syifa Aulia Mahadevi \& Nadia Asandimitra Haryono. Pengaruh Status Quo, Herding Behaviour, Representativeness Bias, Mental Accounting, serta Regret Aversion Bias terhadap Keputusan Investasi Investor Milenial di Kota Surabaya

risiko yang muncul yaitu kesalahan dalam melaksanakan keputusan yang diambil. Hal ini disebabkan karena tindakan tidak tepat sehingga investor merepresentasikanya dalam pengambilan keputusan dan menyesali fakta bahwa mereka telah melakukannya, yang kedua adalah kesalahan kelalaian di mana hal ini terjadi karena seorang investor telah kehilangan peluang yang ada untuk mencapai keuntungan yang diinginkan. Sukamulja, Meilita, \& Senoputri (2019) membagi indikator sebagai alat ukur regret aversion bias menjadi tiga yaitu pengalaman seorang investor saat kehilangan investasinya, adanya perasaan menyesal saat melakukan investasi, bagaimana dampak dari pengalaman kerugian akibat investasi.

\section{Hubungan Antar Variabel}

Status quo bias merupakan sebuah perilaku investor dalam pengambilan keputusan yang berpegang pada keadaan investasi tidak proporsional sehingga cenderung mempertahankan keadaan saat ini walaupun hasilnya tidak maksimal (Umairah, 2012). Status quo bias dijelaskan melalui behaviour finance theory yang memaparkan bahwa perilaku status quo bias memungkinkan seorang investor tetap bertahan dalam kondisi yang tidak proporsional karena memiliki perasaan nyaman pada keadaan yang dilakukan sehingga tidak mau melakukan penyesuaian investasinya (Pradana, 2018). Status quo bias berpengaruh terhadap keputusan investasi seseorang dengan didukung oleh Pradana (2018), Brown \& Kagel (2009), Umairah (2012). Namun tidak sejalan dengan Akinkoye \& Bankole (2020), dan Bashir et al. (2013) bahwa status quo tidak berpengaruh signifikan terhadap keputusan investasi. Dalam hal ini seorang investor cenderung memilih saham yang mereka kenali dan menghindari saham yang menurut mereka dapat berisiko tinggi dan belum pernah diketahui sebelumnya (Umairah, 2012).

H1: Status quo bias berpengaruh terhadap keputusan investasi investor milenial di Kota Surabaya.

Herding behavior merupakan sebuah motif ikut-ikutan yang dilakukan seorang investor mengenai keputusan investor lain saat tidak adanya faktor kepercayaan diri dan kurangnya penguasaan pengetahuan terkait saham yang ingin diinvestasikan (Khalid et al., 2018). Perilaku herding behaviour menyebabkan investor bertindak irasional dan bereaksi cepat terhadap perubahan keputusan investor lain tanpa melihat risiko yang mungkin muncul (Madaan \& Singh, 2019). Hal ini dapat membuktikan bahwa dalam pengambilan keputusan terdapat hubungan antara emosi dan rasionalitas dalam diri investor. Herding behaviour dijelaskan oleh behaviour finance theory yang menyatakan bahwa perilaku herding berasal dari emosi dan ketertarikan terhadap keputusan investor lain yang dapat menyebabkan perilaku irrasional (Mutawally \& Haryono, 2019). Herding behaviour mempunyai pengaruh terhadap keputusan investasi di mana ketika tingkat herding behaviour tinggi maka keputusan investasi yang dibuat semakin tidak rasional. Hasil ini sejalan dengan penelitian dari Afriani \& Halmawati (2019), Akinkoye \& Bankole (2020), Madaan \& Singh (2019), Mahmood et al. (2020), serta Mutawally \& Haryono (2019) bahwa herding berpengaruh signifikan terhadap keputusan investasi, namun berbeda dengan Gozalie \& Anastasia (2015), Subash (2012), dan Khalid, Javed, \& Shahzad (2018) bahwa herding behaviour tidak memengaruhi keputusan investasi.

H2: Herding behaviour berpengaruh terhadap keputusan investasi investor milenial di Kota Surabaya.

Representativeness adalah perilaku dalam pengambilan keputusan investasi yang menyebabkan hasil investasi tidak maksimal dikarenakan pemikiran stereotip atau analogi yang dimiliki investor (Sina, 2014). Trand harga dan karakteristik perusahaan yang bagus akan menjadi salah satu faktor pendorong keputusan investasi investor yang mempunyai representativeness bias (Putri \& Halmawati, 2020). Representativeness bias dijelaskan oleh heuristic theory yang menyatakan bahwa perilaku stereotip atau sejauh mana kemiripan suatu peristiwa dengan peristiwa lain memengaruhi keputusan investasi seorang investor (Pompian, 2007). Hal ini didukung oleh penelitian dari Putri \& Halmawati (2020), Budiman \& Ervina (2020), dan Subash (2012) bahwa representativeness bias berpengaruh terhadap keputusan investasi, dan bertolak belakang dengan Irjayanti \& Kurniawati (2017), representativeness yang menyebutkan bahwa representativeness tidak berpengaruh terhadap keputusan investasi. Seorang investor cenderung mengandalkan pengalaman masa lalu yang dimiliki 
daripada fokus terhadap keuntungan yang akan diperoleh (Budiman \& Ervina, 2020). Semakin tinggi representativeness bias yang dimiliki seorang investor maka semakin sering investor tersebut melakukan keputusan investasi.

H3: Representativeness berpengaruh terhadap keputusan investasi investor milenial di Kota Surabaya.

Mental accounting adalah perilaku menggolongkan keuangan kedalam rekening berbeda berdasarkan maksud penggunaan dana dan sumber pendapatan yang dimiliki (Priantinah \& Si, 2018). Adanya mental accounting yang dimiliki membuat investor semakin berhati hati dalam keputusan investasinya dan memikirkan ulang risiko yang mungkin muncul dari keputusan yang diambil akibat adanya penggolongan keuangan berdasarkan sumber dan pengeluaran dana tersebut (Abdani \& Nurdin, 2019). Mental accounting disebutkan dalam prospect theory bahwa keputusan yang diambil saat keadaan yang tidak pasti dan berisiko akan diambil berdasarkan keadaan yang sebenarnya (Santi, Sahara, \& Kamaludin 2019). Hal ini didukung oleh penelitian dari Santi, Sahara, \& Kamaludin (2019), Sari (2015), dan Abdani \& Nurdin (2019) bahwa mental accounting berpengaruh terhadap keputusan investasi. Namun tidak sesuai dengan Bashir et al. (2013), dan Subash (2012) bahwa tidak terdapat pengaruh antara mental accounting terhadap keputusan investasi. Semakin tinggi tingkat mental accounting seorang investor maka investor tersebut akan semakin mempertimbangkan tingkat risiko yang mungkin muncul dari keputusan investasi yang akan diambil.

H4: Mental accounting berpengaruh terhadap keputusan investasi investor milenial di Kota Surabaya.

Regret aversion bias merupakan sebuah perilaku berlebihan terhadap rasa menyesal terhadap pengambilan keputusan yang salah di masa lalu. Perilaku ini menyebabkan investor tidak mau menjual instrumen yang dia miliki namun memertahankanya dalam waktu lama yang seharusnya bisa memperoleh keuntungan (Budiarto, 2017). Hal ini berarti regret aversion bias memiliki pengaruh terhadap keputusan investasi yang selaras dengan penelitian Budiarto (2017), Pradana (2018), Putri \& Hikmah (2020), Nurdinda, Muslihat, \& Putra (2020), Akinkoye \& Bankole (2020) serta Subash (2012). Namun hasil ini tidak sesuai dengan penelitian Budiman \& Ervina (2020) regret aversion bias tidak berpengaruh terhadap keputusan investasi. Semakin tinggi perilaku regret aversion bias yang dimiliki maka semakin bimbang dan berhati hari seorang investor menentukan keputusan investasinya.

H5: Regret aversion bias berpengaruh terhadap keputusan investasi investor milenial di Kota Surabaya.

\section{METODE PENELITIAN}

Penelitian ini menggunakan jenis penelitian konklusif kausalitas. Sumber data penelitian adalah data primer. Teknik pengumpulan data melalui penyebaran kuisioner secara online. Populasi dalam penelitian ini adalah investor milenial yang telah terdaftar di Kustodian Sentral Efek Indonesia (KSEI) dan securitas yang berada di Kota Surabaya. Metode pengambilan sampel menggunakan metode purposive sampling dan snowball sampling. Kriteria dalam penentuan sampel yaitu investor milenial yang berusia 20 hingga 30 tahun yang telah terdaftar di Kustodian Sentral Efek Indonesia (KSEI) dan perusahaan securitas di Kota Surabaya, serta pernah melakukan transaksi trading saham minimal satu kali setelah mendaftar di Bursa Efek Indonesia. Metode analisis menggunakan Structural Equation Model (SEM) dengan program AMOS. Skala Likert skor 1 hingga 4 digunakan untuk mengukur respon dari responden pada status quo bias, herding behaviour, representativeness, mental accounting, serta regret aversion bias. Skor dari setiap item pada masing masing variabel dijumlah dan dirata-rata untuk mengetahui bobot jawaban responden dengan menggunakan dasar kriteria three box method. Tahapan analisis data dimulai dari uji outliers dan uji normalitas. Selanjutnya dilakukan uji validitas dan reliabilitas. Setelah data dinyatakan valid dan reliabel, maka dilanjutkan pada tahap 
Syifa Aulia Mahadevi \& Nadia Asandimitra Haryono. Pengaruh Status Quo, Herding Behaviour, Representativeness Bias, Mental Accounting, serta Regret Aversion Bias terhadap Keputusan Investasi Investor Milenial di Kota Surabaya

selanjutnya yaitu uji kelayakan model dan uji hipotesis, serta uji model pengukuran dengan determinasi.

\section{HASIL DAN PEMBAHASAN}

\section{Uji Outlier}

Uji outlier dilakukan dengan melihat nilai mahalanobis distance menggunakan kriteria p2 <0,001 sebagai data yang lolos outlier. Berdasarkan hasil pengujian ditemukan 32 data yang tidak lolos uji outlier yaitu pada nomor obervasi 60, 43, 185, 90, 182, 194, 193, 143, 67, 88, 46, 49, 128, 69, 205, $151,59,9,130,179,113,214,4,739,86,183,157,19,15,228,51,12$ karena nilai p2 <0,001. Data yang masuk dalam outlier harus dieliminasi sehingga tersisa 209 data yang dapat diolah pada tahapan uji selanjutnya.

\section{Uji Normalitas}

Uji normalitas dilakukan untuk mengetahui apakah data berdistribusi normal atau tidak, dengan melihat nilai assasesment of normality dengan ketentuan data dikatakan normal ketika memenuhi syarat maximum likehood dengan nilai critical ratio diantara -2,58 sampai 2,58. Berdasarkan hasil uji dengan melihat nilai assasesment of normality diketahui bahwa item SQ2, HE2, RE6, RE7, MA3, MA4, MA5, MA6, RAB1, KI2, KI3, KI7 mempunyai nilai c.r skewness lebih dari $\pm 2,58$ sehingga data dinyatakan tidak berdistribusi normal dan item harus dieliminasi untuk tahapan uji selanjutnya.

\section{Uji Validitas}

Uji validitas dilihat dari nilai discriminant validity. Ketentuan lolos uji validitas jika nilai perhitungan variabel discriminant validity $>0,500$ yang diperoleh dari akar kuadrat variance exreacted. Berdasarkan hasil perhitungan didapatkan keseluruhan nilai discriminant validity $>0,500$ sehingga data dapat dinyatakan valid.

\section{Uji Reliabilitas}

Uji reliabilitas digunakan untuk mengetahui tingkat konsistensi suatu kuisioner dalam penelitian. Sebuah data dinyatakan lolos uji realiabel ketika nilai construct reliability $>0,500$. Berdasarkan hasil penelitian diperoleh bahwa seluruh item dapat dinyatakan reliabel karena nilai construct reliability masing masing item $>0,500$.

\section{Uji Kelayakan Model}

Uji kelayakan model menggunakan goodness of fit indices. Hasil nilai uji GFI sebesar 0,935, AGFI sebesar 0,905, dan TLI sebesar 0,981 dalam kategori baik karena nilai melebihi batas ketentuan yaitu $>0,900$. Sedangkan hasil uji RMSEA dan NFI dalam kategori marginal karena nilai kurang dari batas ketentuan. Nilai dalam uji goodness of fit indices dalam tabel 1 adalah hasil akhir setelah dilakukan modification indices untuk mendapatkan model yang fit pada amos, karena pada awal pengujian nilai GFI, AGFI dan TLI masih tergolong rendah.

Tabel 1.

\section{UJI GOODNESS OF FIT INDICES}

\begin{tabular}{cccc} 
Goodness of Fit Indices & Batas & Hasil & Keputusan \\
\hline GFI & $>0,900$ & 0,935 & Baik \\
AGFI & $>0,900$ & 0,905 & Baik \\
TLI & $>0,900$ & 0,981 & Baik \\
RMSEA & $0,080 \leq$ dan $\geq 0,050$ & 0,022 & Marginal \\
NFI & $>0,900$ & 0,873 & Marginal \\
\hline
\end{tabular}

Sumber : Amos Output (Data diolah penulis, 2021) 
Uji kelayakan model pada penelitian ini dapat diterima karena terdapat 3 dari 5 kriteria dalam uji goodness of fit indices yang menunjukkan kategori baik, sehingga menghasilkan model akhir pada gambar 3.

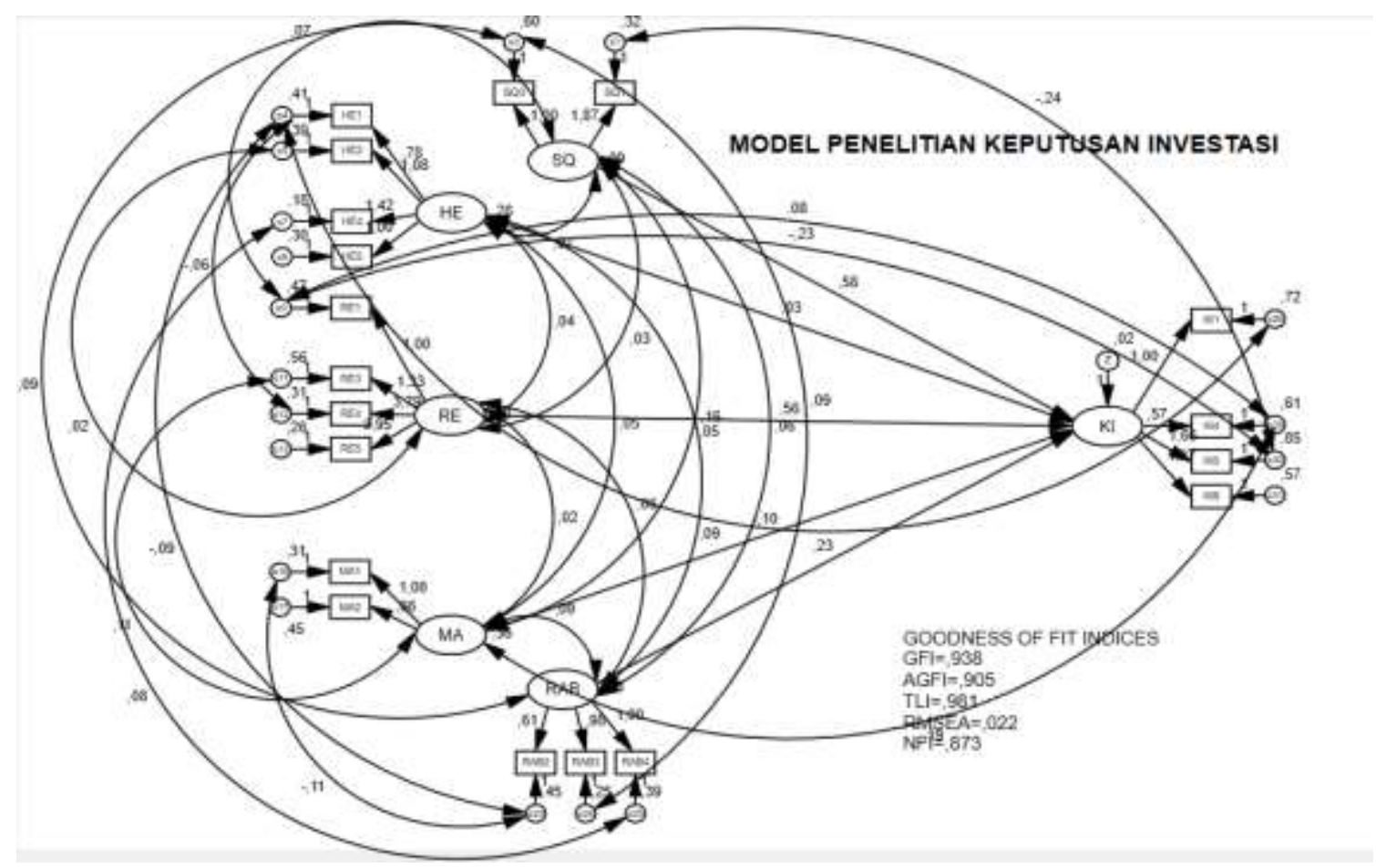

Sumber : Amos Output (Data diolah penulis, 2021)

Gambar 3. MODEL AKHIR SEM

Hasil uji hipotesis berdasarkan kriteria jika pengaruh antar variabel memiliki nilai CR hitung $\geq 2,00$ dan probabilitas signifikansi $(\mathrm{P}) \leq 0,05$ maka pengaruh antar variabel tersebut signifikan atau terdapat pengaruh antara variabel independen terhadap variabel dependen. Hasil Pengujian pada tabel 2, H1 dan $\mathrm{H} 5$ dapat diterima karena nilai $\mathrm{CR}$ hitung $\geq 2,00$ yaitu 2,320 dan 2,813 serta nilai $\mathrm{P} \leq 0,05$ yaitu 0,02 dan 0,00 . Sedangkan H2, H3, dan H4 ditolak karena memiliki nilai CR hitung $\leq 2,00$ yaitu sebesar 0,404, 1,523, dan $-1,407$ dan nilai $\mathrm{P} \geq 760,05$ yaitu sebesar $0,686,0,128$, dan 0,159.

Tabel 2.

UJI GOODNESS OF FIT INDICES

\begin{tabular}{ccccccc}
\hline Hipotesis & Variabel & Estimate & S.E & C.R & P & Label \\
\hline HI & SQ $\longrightarrow$ KI &, 583 &, 251 & 2,320 &, 020 & par_11 \\
H2 & SQ $\longrightarrow$ KI &, 034 &, 083 &, 404 &, 686 & par_12 \\
H3 & SQ $\longrightarrow$ KI &, 562 &, 369 & 1,523 &, 128 & par_13 \\
H4 & SQ $\longrightarrow$ KI &,- 102 &, 072 & $-1,407$ &, 159 & par_14 \\
H5 & SQ $\longrightarrow$ KI &, 234 &, 083 & 2,813 &, 005 & par_15 \\
\hline
\end{tabular}

Sumber : Amos Output (Data diolah penulis, 2021)

Hasil analisis model pengukuran menggunakan koefisien determinasi dapat dilihat berdasarkan nilai square multiple correlation untuk keputusan investasi dikali 100\%. Berdasarkan hasil analisis besar nilai square multiple correlation adalah $0,864 \times 100 \%=86 \%$. Yang berarti bahwa keputusan investasi dijelaskan oleh variabel independen sebesar 86\%, sedangkan 14\% dijelaskan oleh faktor lain diluar variabel yang dibahas dalam penelitian ini. Variabel lain yang dapat menjelaskan variabel keputusan investasi diantaranya adalah variabel financial dissonancel literacy, cognitiv disconance, loss aversion bias yang pernah diteliti oleh Pradana (2018), variabel heuristic, anchoring, gambler's fallacy, availability yang telah diteliti oleh Gozalie \& Anastasia (2015). 
Syifa Aulia Mahadevi \& Nadia Asandimitra Haryono. Pengaruh Status Quo, Herding Behaviour, Representativeness Bias, Mental Accounting, serta Regret Aversion Bias terhadap Keputusan Investasi Investor Milenial di Kota Surabaya

\section{Pengaruh Satus Quo terhadap Keputusan Investasi}

Hasil uji hipotesis variabel status quo berpengaruh signifikan terhadap keputusan investasi. Berdasarkan hasil rata-rata jawaban responden menunjukkan bahwa responden setuju untuk terus mempertahankan keadaan saat ini atau sebelumnya serta memilih berinvestasi pada surat berharga yang disukai dan dirasa familiar dalam pengambilan keputusan investasi karena telah merasa nyaman dan aman dalam kondisi tersebut, sehingga cenderung menghindari perubahan karena takut akan ketidakpastian di masa depan walaupun secara analisis dan informasi yang ada menyatakan bahwa aset investasi yang akan mereka ambil itu akan menguntungkan. Hasil penelitian ini mendukung behavioral finance theory yang menjelaskan bahwa tindakan seseorang dasari pada psikologinya. Selain itu sikap irrasional juga memengaruhi perilaku seseorang (Fridana \& Asandimitra, 2020). Semakin tinggi tingkat status quo seorang investor milenial maka semakin tinggi risiko pengambilan investasi yang kurang maksimal dan cenderung melewatkan peluang pasar yang ada. Investor dengan status quo bias akan menimbang potensi kerugian daripada keuntungan yang didapat sehingga mereka hanya akan berubah ketika keuntungan lebih besar daripada risiko investasinya (Pradana, 2018). Berdasarkan pendapatan mayoritas responden adalah kurang dari Rp1.500.000 dengan persentase sebesar 47,3\%, di mana ketika modal yang mereka gunakan untuk untuk berinvestasi masih minim, maka mereka cenderung takut akan risiko potensi kerugian sehingga memilih untuk tetap bermain aman dan berinvestasi pada saham perusahaan yang dirasa familiar. Hasil penelitian ini sejalan dengan Pradana (2018), Umairah (2012) yang menyebutkan bahwa status quo berpengaruh signifikan terhadap keputusan investasi. Investor cenderung akan bermain aman dan memilih saham perusahaan yang telah familiar, dan menghindari saham yang belum terlalu investor tersebut ketahui yang dapat menghasilkan risiko tinggi.

\section{Pengaruh Herding Behaviour terhadap Keputusan Investasi}

Hasil uji hipotesis variabel herding behaviour tidak berpengaruh signifikan terhadap keputusan investasi. Hasil ini juga didukung oleh jawaban mayoritas responden terhadap pertanyaan kuisioner bahwa terdapat faktor-faktor lain yang memengaruhi proses pengambilan keputusan investasi investor milenial selain herding behaviour, seperti pengetahuan dan analisis teknikal dan fundamental yang mereka lakukan secara pribadi. Mayoritas responden dalam penelitian ini adalah mahasiswa dengan persentase sebesar 53,9\%, artinya mereka masih dalam proses studi sehingga memudahkan untuk mendapatkan ilmu dan pengetahuan terkait investasi, hal ini juga didukung dengan tersebarnya galeri investasi pada perguruan tinggi yang mengadakan pelatihan-pelatihan terkait cara analisis serta investasi saham suatu perusahaan. Berdasarkan dari usia mayoritas responden yaitu investor milenial yang berusia 20 hingga 25 tahun, di mana dalam usia ini mereka dapat mengoptimalkan media social yang mereka miliki dengan lebih baik sebagai sarana memperoleh informasi dan pengetahuan seputar investasi. Hasil penelitian ini tidak mendukung behavior finance theory yang mendasari bahwa seseorang sering kali menambahkan faktor psikologi, emosi, sifat, kesukaan dan perilaku yang ada pada diri mereka yang membuat keputusan yang mereka pilih menjadi irrasional (Kahneman \& Tversky, 1979). Hasil ini didukung Gozalie \& Anastasia (2015), Subash (2012), dan Khalid, Javed, \& Shahzad (2018) bahwa tidak ada pengaruh signifikan antara herding dengan keputusan investasi.

\section{Pengaruh Representativeness terhadap Keputusan Investasi}

Variabel representativeness tidak berpengaruh signifikan terhadap keputusan investasi. Berdasarkan jawaban mayoritas responden, responden cenderung melihat bagaimana keadaan perusahaan dari sisi kualitas, kemampuan lukuiditas dan kehandalan untuk beroperasi dan bersaing dengan perusahaan lain bukan hanya sekedar melihat trand harga dan keadaan perusahaan. Dalam penelitian ini mayoritas responden sebagai mahasiswa dengan persentase sebesar 53,9\%, mereka masih dalam proses studi sehingga memudahkan untuk mendapatkan ilmu dan pengetahuan terkait analisis investasi mulai dari analisis teknikal dan fundamental. Mayoritas responden juga telah berinvestasi selama lebih dari 6 bulan dengan jumlah transaksi lebih dari $3 \mathrm{kali}$, hal ini mengindikasikan bahwa responden telah memiliki pengalaman sehingga lebih berhati hati dalam mengambil keputusan investasinya. Hasil penelitian ini tidak mendukung heuristic theory, bahwa seorang investor membuat keputusan berdasarkan stereotip (Pompian, 2007). Hasil penelitian ini sejalan dengan penelitian Irjayanti \& Kurniawati (2017) bahwa representativeness bias tidak berpengaruh secara signifikan terhadap 
keputusan investasi, di mana dalam pengambilan keputusan investasi diperlukan adanya kemampuan dan analisis yang mendalam agar mendapatkan keuntungan yang maksimal.

\section{Pengaruh mental accounting terhadap keputusan investasi}

Variabel mental accounting tidak berpengaruh signifikan terhadap keputusan investasi. Dalam pengambilan keputusan investasi, responden dalam penelitian ini mempertimbangkan perbandingan antara manfaat dan biaya investasi yang akan diambil sebelum melakukan keputusan. walaupun investor menyisihkan dan menggolongkan keuangnya untuk kepentingan investasi, mereka tidak langsung membelanjakan uang tersebut untuk berinvestasi, namun mereka juga melakukan analisis yang mendalam sebelum memutuskan memilih jenis saham yang dipilihnya. Dalam penelitian ini sebagian besar responden memiliki usia 20 hingga 25 tahun di mana dalam usia ini responden masih kesulitan dalam mengelola keuangan mereka. Dilihat dari karakteristik pendapatan responden mayoritas memiliki pendapatan kurang dari Rp1.500.000 dan berprofesi sebagai mahasiswa, tentunya akan sulit dalam mengelola keuangan dikarenakan kecenderungan mahasiswa yang masih berpola pikir fokus terhadap studi mereka dan keinginan lainnya. Penelitian ini tidak mendukung prospect theory yang menyatakan a ada bias yang terus menerus dimotivasi oleh faktor-faktor psikologis memengaruhi pilihan individu dalam kondisi ketidakpastian. Hasil ini didukung oleh Sari (2015), Subash (2012), Bashir et al. (2013), terdapat pengaruh tidak signifikan antara variabel mental accounting terhadap keputusan investasi.

\section{Pengaruh Regret Aversion Bias terhadap Keputusan Investasi}

Variabel regret aversion bias berpengaruh signifikan terhadap keputusan investasi. Hal ini disebabkan karena responden masih merasa takut terhadap risiko kerugian yang mungkin dihadapi ketika mereka memilih untuk melakukan investasi baru daripada keputusan investasi lama mereka. Mayoritas responden dalam penelitian ini masih berusia 20 hingga 25 tahun, dalam usia ini responden masih memiliki perasaan takut terhadap investasi pada saham yang sama karena pernah mengalami kerugian. Penelitian ini mendukung prospect theory yang menegaskan bahwa seseorang tidak selalu bertindak rasional dibawah risiko dan ketidakpastian. Hasil penelitian ini selaras dengan Pujiyanto \& Mahastanti (2013), Budiarto (2017), Putri \& Hikmah (2020), Nurdinda et al. (2020), Subash (2012), Akinkoye \& Bankole (2020) bahwa ada pengaruh signifikan regret aversion bias terhadap keputusan investasi. Hal ini menunjukkan bahwa responden dalam penelitian ini mudah mengalami regret aversion sehingga membuat efek trauma pada investasinya di masa depan.

\section{KESIMPULAN}

Berdasarkan hasil penelitian serta pembahasan yang telah dipaparkan, maka dapat diketahui bahwa terdapat pengaruh yang signifikan antara variabel status quo dan variabel regret aversion bias terhadap keputusan investasi investor milenial di Kota Surabaya. Hal ini menerangkan bahwa responden pada penelitian ini memilih untuk berada pada kondisi yang sama dan memilih portofolio yang dirasa familiar dan disukai, dan juga mereka cenderung menolak perubahan karena rasa takut akan risiko kerugian yang mungkin dihadapi di masa depan. Sementara itu, variabel herding behaviour, representativeness, serta mental accounting tidak berpengaruh signifikan terhadap keputusan investasi investor milenial di Kota Surabaya. Hal ini menerangkan bahwa dalam pengambilan keputusan responden juga masih menggunakan pengetahuan serta analisis sebagai pertimbangan dalam proses keputusan investasi.

Saran yang dapat diberikan berdasarkan hasil penelitian ini bagi investor milenial hendaknya memerhatikan dengan baik bias yang ada pada dirinya, terutama status quo dan regret aversion bias yang berpengaruh signifikan terhadap keputusan investasi. Diharapkan investor milenial dapat lebih berhati hati dan mendalami pengetahuan serta ilmu terkait investasi dengan memanfaatkan teknologi yang ada secara maksimal demi membuat keputusan investasi yang lebih baik. Hendaknya investor milenial juga selalu memerhatikan informasi pasar dan kesiapan financial demi menghindari keputusan investasi yang merugikan dan memberikan keuntungan yang diharapkan dimasa medatang. Bagi Otoritas Jasa Keuangan (OJK) hendaknya memberikan sosialisasi kepada masyarakat terutama 
Syifa Aulia Mahadevi \& Nadia Asandimitra Haryono. Pengaruh Status Quo, Herding Behaviour, Representativeness Bias, Mental Accounting, serta Regret Aversion Bias terhadap Keputusan Investasi Investor Milenial di Kota Surabaya

generasi milenial mengenai pengetahuan, keuntungan serta cara berinvestasi yang baik dan benar demi menambah minat dan kualitas pengetahuan investor milenial terkait investasi, serta mengurangi aspek bias yang dimiliki investor milenial agar menciptakan investasi yang menguntungkan dan berkualitas dalam rangka meningkatkan pertumbuhan ekonomi nasional. Sedangkan bagi peneliti selanjutnya diharapkan mampu mengukur pengaruh variabel terhadap keputusan investasi dari variabel yang lebih kompleks, mengingat masih ada 14\% keputusan investasi yang dipengaruhi oleh variabel lain selain yang dibahas dalam penelitian ini. Peneliti selanjutnya disarankan memilih investor yang aktif sebagai responden penelitian agar hasil penelitian dapat lebih akurat. Serta menggunakan variabel yang belum dibahas dalam penelitian ini, seperti variabel financial dissonancel literacy, cognitiv disconance, loss aversion bias variabel heuristic, anchoring, gambler's fallacy, availability.

\section{DAFTAR PUSTAKA}

Abdani, F., \& Nurdin, F. (2019). Kausalitas Mental Accounting dan Pengambilan Keputusan Investasi Mesin Produksi: Suatu Studi Eksperimen. Akuntabilitas, 12(2), 145-156. https://doi.org/10.15408/akt.v12i2.11703

Ackert, L. F., \& Deaves, R. (2010). Noor, J., 2010. Metodologi Penelitian Skripsi, Tesis, Disertasi, dan Karya Ilmiah. Jakarta: Kencana Prenada Media Grup.

Afriani, D., \& Halmawati. (2019). Pengaruh cognitive dissonance bias, overconfidence bias dan herding bias terhadap pengambilan keputusan investasi. Jurnal Eksplorasi Akuntansi, 1(4), 1650-1665. http://jea.ppj.unp.ac.id/index.php/jea/issue/view/14

Akinkoye, E. Y., \& Bankole, O. E. (2020). Effect of Emotional Biases on Investor's Decision Making in Nigeria. International Journal of Business and Management Future, 4(1), 33-39. https://doi.org/10.46281/ijbmf.v4i1.548

Bashir, D. T., Javed, A., Ali, U., Meer, U. I., \& Naseem, M. M. (2013). Empirical Testing Of Heuristics Interrupting The Investor's Rational Decision Making. European Scientific Journal, 9(28), 185-191. https://doi.org/10.1109/GLSV.1998.665223

Brown, A. L., \& Kagel, J. H. (2009). Behavior in a simplified stock market: The status quo bias, the disposition effect and the ostrich effect. Annals of Finance, 5(1), 1-14. https://doi.org/10.1007/s10436-007-0092-0

Budiarto, A. (2017). Pengaruh Financial Literacy, Overconfidence, Regret Aversion Bias, Dan Risk Tolerance Terhadap Keputusan Investasi (Studi Pada Investor Pt. Sucorinvest Central Gani Galeri Investasi Bei Universitas Negeri Surabaya) Angga Budiarto. Jurnal Ilmu Manajemen Volume, 05, 1-9.

Budiati, I., Susianto, Y., Adi, W. P., Ayuni, S., Reagan, H. A., Larasaty, P., Setiyawati, N., Pratiwi, A. I., \& Saputri, V. G. (2018). Profil Generasi Milenial Indonesia. Jakarta: Kementerian Pemberdayaan Perempuan dan Perlindungan Anak

Budiman, J., \& Ervina. (2020). Pendekatan Perilaku Keuangan Terhadap Keputusan Investasi Emas. Jurnal Profit, 14(1), 63-68. https://www.kompasiana.com/dindaidho/585f69f074937358063966c0/investasi-emas

Fridana, I. O., \& Asandimitra, N. (2020). Analisis Faktor Yang Memengaruhi Keputusan Investasi (Studi Pada Mahasiswi Di Surabaya). Jurnal Muara Ilmu Ekonomi Dan Bisnis, 4(2), 396. https://doi.org/10.24912/jmieb.v4i2.8729 
Gozalie, S., \& Anastasia, N. (2015). Pengaruh Perilaku Heuristics dan Herding Terhadap Pengambilan Keputusan Investasi Properti Hunian. Finesta, 3(2), 28-32.

Gupta, C. (2019). Regret aversion bias and financial risk tolerance. International Journal of Commerce and Management Research International, 5(2), 99-104.

Irjayanti, D., \& Kurniawati, S. L. (2017). Pengaruh Literasi Keuangan, Representativeness, Familiarity, dan Persepsi Risiko Terhadap Pengambilan Keputusan Investasi Pada Investor Surabaya dan Sidoarjo. Jurnal Ilmu Manajemen, 5(9), 1-17.

Kahneman, D., \& Tversky, A. (1979). Prospect Theory: An Analysis of Decision under Risk. The Econometric Society, 47(2), 263-291.

Khalid, R., Javed, M. U., \& Shahzad, K. (2018). Impact of Behavioral Biases on Investment Decision Making with Moderat- ing Role of Financial Literacy Literature Review Investment Decision. Jinnah Business Review, 6(2), 34-41.

Kontan, H. (2019). Akuntansi Mental. (https://kolom.kontan.co.id/news/akuntansi-mental/ Diakses pada 25 November 2020)

KSEI. (2019). 22 Tahun KSEI: Mendukung Pengembangan Infrastruktur Untuk Kenyamanan Investasi di Pasar Modal. 1-3. (https://www.ksei.co.id/ Diakses pada 16 November 2020)

KSEI. (2020). PT Kustodian Sentral Efek Indonesia. (https://www.ksei.co.id/ Diakses pada 16 November 2020)

Lanka, S., \& Kengatharan, N. (2014). The Influence of Behavioral Factors in Making Investment Decisions and Performance: Study on Investors of Colombo Stock Exchange, Sri Lanka. Asian Journal of Finance \& Accounting, 6(1), 1-23. https://doi.org/10.5296/ajfa.v6i1.4893

Luong, L. P., \& Ha, D. T. T. (2011). Behavioral Factors Influencing Individual Investors' DecisionMaking and Performance: A Survey at the Ho Chi Minh Stock Exchange. In Umea: Umea Universitet.

Madaan, G., \& Singh, S. (2019). An analysis of behavioral biases in investment decision-making. International Journal of Financial Research, 10(4), 55-67. https://doi.org/10.5430/ijfr.v10n4p55

Mahmood, T., Ayyub, R. M., Imran, M., Naeem, S., \& Abbas, W. (2020). the Behavioral Analysis and Financial Performance of Individual Investors At Pakistan Stock Exchange. International Journal of Economics and Financial Issues, 10(5), 158-164. https://doi.org/10.32479/ijefi.10112

Mutawally, F. W., \& Haryono, N. A. (2019). Pengaruh Financial Literacy, Risk Perception, Behavioral Finance Dan Pengalaman Investasi Terhadap Keputusan Investasi Mahasiswa Surabaya. Jurnal Ilmu Manajemen (JIM), 7(4), 942-953.

Noor, J. (2010). Metodologi Penelitian Skripsi, Tesis, Disertasi, dan Karya Ilmiah. Jakarta: Kencana Prenada Media Grup.

Nurdinda, W., Muslihat, A., \& Putra, R. A. K. (2020). Pengaruh Regret Aversion Bias dan Risk Tolerance Bagi Investor Muda Jawa Barat terhadap Keputusan Investasi. Jurnal Akuntansi Dan Keuangan, 1(1), 30-38. http://jurnal.poliupg.ac.id/index.php/akunsika

Pompian, M. M. (2006). Behavioral Finance and Wealth Management - How to Build Optimal Portfolios That Account for Investor Biases. Hoboken: John Wiley \& Sons, Inc. 
Syifa Aulia Mahadevi \& Nadia Asandimitra Haryono. Pengaruh Status Quo, Herding Behaviour, Representativeness Bias, Mental Accounting, serta Regret Aversion Bias terhadap Keputusan Investasi Investor Milenial di Kota Surabaya

Pompian, M. M. (2007). Behavioral Finance and Wealth Management - How to Build Optimal Portfolios That Account for Investor Biases. In Financial Markets and Portfolio Management (Vol. 21, Issue 4). https://doi.org/10.1007/s11408-007-0065-3

Pradana, R. W. (2018). Pengaruh Financial Literacy, Cognitive Bias, Dan Emotional Bias Terhadap Keputusan Investasi (Studi Pada Investor Galeri Investasi Universitas Negeri Surabaya). Jurnal Ilmu Manajemen (JIM), 6(3), 108-117.

Pradikasari, E., \& Isbanah, Y. (2018). Pengaruh Financial Literacy, Illusion of Control, Overconfidence, Risk Tolerance, dan Risk Perception Terhadap Keputusan Investasi Pada Mahasiswa di Kota Surabaya. Jurnal Ilmu Manajemen (JIM), 6(4), 424-434.

Prawirasasra, K. P., \& Dialysa, F. (2015). Implikasi Behavioral Finance Pada Proses Pengambilan Keputusan Investasi Di Masa Pensiun. Jurnal Sekolah Tinggi Ilmu Ekonomi, 21-36.

Priantinah, D., \& Si, M. (2018). Mental Accounting Dalam Proses Pengambilan Keputusan Investasi. Jurnal Akuntansi, 6(1), 75-87.

Pujiyanto, N., \& Mahastanti, L. A. (2013). Regret Aversion Bias Dan Risk Tolerance Dalam Keputusan Investasi. Journal \& Proceeding, 3(1), 281-286.

Putri, \& Hikmah. (2020). Pengaruh Financial Literacy, Overconvidence, regret Avertion Bias, dan Risk Tolerance terhadap Investment Decision di Kota Batam. Jurnal Ilmiah Maksitek, 5(2), 95109.

Putri, S., \& Halmawati. (2020). Pengaruh Financial Literacy, Representativeness Bias, Dan Bias Optimisme Terhadap Pengambilan Keputusan Investasi. Jurnal Eksplorasi Akuntansi, 2(3), 2976-2991. http://jea.ppj.unp.ac.id/index.php/jea/issue/view/25

Ramdani, F. N. (2016). Analisis Pengaruh Representativeness Bias dan Herding Behaviour Terhadap Keputusan Investasi (Studi pada Mahasiswa di Yogyakarta). 4(1), 64-75. https://dspace.uii.ac.id/

Ratnadi, N. M. D., Widanaputra, A. A. G. P., \& Putra, I. N. W. A. (2020). Behavioral Factors Influencing Investment Decision-Making By College Student: An Empirical Study In Bali Province, Indonesia. International Journal of Scientific \& Technology Research, 9(02), 13581368.

Ross, S. A., Westerfield, R. W., Jordan, B. D., \& Joseph Lim, R. T. (2016). Pengantar Keuangan Perusahaan: Fundamentals of Corporate Finance (edisi global asia buku 2). Salemba Empat.

Santi, F., Sahara, N. V., \& Kamaludin. (2019a). Pengaruh Akuntansi Mental Terhadap Siswa Keputusan Investasi : Studi Di Investasi Galeri ( Gi ) Feb Universitas Bengkulu Dan Syariah. Jurnal Ilmiah Ekonomi Bisnis, 24(2), 1-16.

Santi, F., Sahara, N. V., \& Kamaludin. (2019b). the Effect of Mental Accounting on Student'S Investment Decisions: a Study At Investment Gallery (Gi) Feb University of Bengkulu and Syariah Investment Gallery (Gis) Feb Iain Bengkulu. Journal of Business Economics, 24(2), 152-167. https://doi.org/10.35760/eb.2019.v24i2.1907

Sari, P. M. (2015). Pengaruh Faktor Demografi dan Faktor Psikologis Terhadap Keputusan Investasi. Accounting Analysis Journal, 4(672013167), 0-18.

Sina, P. G. (2014). Representativeness Bias dan Demografi dalam Membuat Keputusan Keuangan. 
Jurnal Manajemen, 14(1), 425-443. https://doi.org/10.1007/978-3-319-93224-8_24

Subash, R. (2012). Role of Behavioral Finance in Portfolio Investment Decisions: Evidence from India. Faculty of Social Science Institute of Economic Studies, 8-9. http://ies.fsv.cuni.cz/default/file/download/id/20803

Sukamulja, S., Meilita, A. Y. N., \& Senoputri, D. (2019). Regret Aversion Bias, Mental Accounting, Overconfidence, and Risk Perception in Investment Decision Making on Generation Y Workers in Yogyakarta. International Journal of Economics and Management Studies, 6(7), 102-110. https://doi.org/10.14445/23939125/ijems-v6i7p116

Syahyunan. (2015). Manajemen Keuangan 1 (Edisi Ketiga). Medan: USU Press.

Tandelilin, E. (2010). Portofolio dan Investasi: Teori dan aplikasi. Yogyakarta: Kanisius.

Ullah, S. (2015). An Empirical Study of Illusion of Control and Self-Serving Attribution Bias, Impact on Investor's Decision Making: Moderating Role of Financial Literacy. Research Journal of Finance and Accounting, 6(19), 109-118.

Umairah, P. (2012). Cognitive Bias dan Emotional Bias dalam Pengambilan Keputusan Investasi Portofolio. Jurnal Online Universitas Kristen Satya Wacana. http:repository.uksw.edu

Widanti, Afrima \& Alfansi, L. (2013). Pengaruh Keterlibatan Fashion (Fashion Involvement) Terhadap Kepercayaan Merek (Brand Trust) Dengan Mediasi Hedonic Value Dan Utilitarian Value (Pada Konsumen Smartphone, Tablet Dan Laptop). Journal Consumer Research, 1, 45117.

Wulandari, D. A., \& Iramani, R. (2014). Studi Experienced Regret, Risk Tolerance, Overconfidance Dan Risk Perception Pada Pengambilan Keputusan Investasi. Journal of Business and Banking, 4(1), 55. https://doi.org/10.14414/jbb.v4i1.293 